\title{
Michel Brix, Le Nez de Cléopâtre, Sainte-Beuve et la philosophie de l'Histoire
}

\section{Laurence Richer}

\section{(2) OpenEdition}

10 Journals

\section{Édition électronique}

URL : http://journals.openedition.org/studifrancesi/8983

DOI : 10.4000/studifrancesi.8983

ISSN : 2421-5856

Éditeur

Rosenberg \& Sellier

\section{Édition imprimée}

Date de publication : 1 octobre 2008

Pagination : 478

ISSN : 0039-2944

\section{Référence électronique}

Laurence Richer, "Michel Brix, Le Nez de Cléopâtre, Sainte-Beuve et la philosophie de l'Histoire », Studi Francesi [En ligne], 155 (LII | II) | 2008, mis en ligne le 30 novembre 2015, consulté le 13 janvier 2021. URL : http://journals.openedition.org/studifrancesi/8983; DOI : https://doi.org/10.4000/studifrancesi. 8983

Ce document a été généré automatiquement le 13 janvier 2021.

\section{(c)}

Studi Francesi è distribuita con Licenza Creative Commons Attribuzione - Non commerciale - Non opere derivate 4.0 Internazionale. 


\title{
Michel Brix, Le Nez de Cléopâtre, Sainte-Beuve et la philosophie de l'Histoire
}

\author{
Laurence Richer
}

\section{RÉFÉRENCE}

MICHEL BRIX, Le Nez de Cléopâtre, Sainte-Beuve et la philosophie de l'Histoire, La Louve éditions, 2007, pp. 154.

1 Le concept de philosophie de l'histoire est intimement lié au romantisme européen. Le court livre de Michel Brix va d'emblée à l'essentiel et peut être considéré comme un essai de définition. L'expression, apparue sous la plume de Voltaire, se charge en effet au siècle suivant d'une interrogation fondamentale pour notre civilisation: «l'histoire est-elle le domaine du contingent et de l'irrationnel, ou le lieu du sens?» (p. 14). C'est donc sur la signification même de l'histoire pour la pensée occidentale que repose ce livre. On voit l'écueil, que les romantiques eux-mêmes n'ont pas toujours évité: entre philosophie, histoire et littérature, le champ est vaste, trop vaste peut-être. S'il est des passages pesants dans les écrits de Michelet, ce sont bien ses références à Joachim de Flore. On connaît aussi l'inquiétante diversité des interprétations de Vico par le XIX siècle français. Or c'est justement par sa clarté, sa précision et sa concision que se signale l'essai présent. Un historique très clair situe les notions en jeu depuis l'Antiquité; pour l'époque moderne, l'auteur concilie une approche européenne, et l'interrogation proprement française, constamment confrontée à la Révolution. La dimension littéraire est présente aussi bien par les mythes les plus productifs, comme le «grand homme» que par le corpus. Celui-ci puise de façon équilibrée dans des textes incontournables et dans d'autres qui étaient difficiles d'accès jusqu'à une date récente. Le scepticisme face à une possible interprétation de l'histoire est illustré par Sainte- 
Beuve et Flaubert. Un dernier chapitre montre l'enjeu pour l'écriture narrative de l'histoire ou du roman.

2 Au-delà de son titre aussi modeste qu'ironique, ce livre peut être considéré comme la meilleure mise au point actuelle sur la philosophie de l'histoire au xIX siècle. Il constitue un moyen d'accès remarquable à la littérature de ce siècle. Il sera utile aux spécialistes comme aux étudiants avancés. Souhaitons-lui une large diffusion. 